\title{
Molecular cloning and genetic characterization of the $r f b$ region from Yersinia pseudotuberculosis serogroup IIA, which determines the formation of the 3,6-dideoxyhexose abequose
}

\author{
Annette C. Kessler, Peter K. Brown, Lajwant K. Romana and Peter R. Reeves* \\ Department of Microbiology, The University of Sydney, Sydney, NSW 2006, Australia
}

(Received 20 May 1991; revised 1 August 1991; accepted 28 August 1991)

\begin{abstract}
The $r f b$ region of Yersinia pseudotuberculosis serogroup IIA has been cloned and expression of $O$ antigen in Escherichia coli $\mathrm{K} 12$ was demonstrated. Transposon mutagenesis analysis confined the DNA region required for $O$ antigen expression to a $19.3 \mathrm{~kb}$ fragment, and the $O$ antigen expressed was visualized by SDS-PAGE and silver staining. Southern hybridization analysis demonstrated significant levels of similarity between the Yersinia $r f b$ region and the 3,6-dideoxyhexose pathway genes $r f b F$ and $r f b G$, previously isolated from Salmonella enterica LT2, but no similarity to the abequose synthase gene $r f b J$ of the same strain or the paratose synthase gene $r f b S$ isolated from S. enterica Ty2. The evolutionary relationship between the abequose biosynthetic genes of the two species of Salmonella and Yersinia is discussed.
\end{abstract}

\section{Introduction}

Lipopolysaccharides (LPS) are important antigens of the cell surface in Gram-negative bacteria, responsible for the serological $O$ specificity of many clinically relevant genera such as Salmonella, Escherichia, Shigella and Yersinia. The immunogenic properties of a given $\mathrm{O}$ antigen are entirely due to the sugar composition and structure of the O-specific polysaccharide moiety, which forms, together with an oligosaccharide core and lipid A, the complete LPS molecule embedded in the outer membrane (Lüderitz et al., 1971). Of a considerable number of monosaccharides identified as components of O-specific polysaccharides, derivatives of the 3,6dideoxyhexose group have attracted particular attention for their highly immunogenic character. Within Gramnegative bacteria, only a limited number of species, all in the family Enterobacteriaceae, is able to form these unusual sugars. Colitose can be found in the LPS of some Escherichia coli serotypes, while $\mathrm{O}$ antigens of some Citrobacter strains contain abequose. In these cases, the repertoire seems to be limited to the synthesis of one particular derivative only in each genus. On the other hand, within Salmonella and Yersinia, a whole variety of 3,6-dideoxyhexoses can be found throughout a spectrum of serotypes. Of the five dideoxyhexoses known to occur naturally, four have been found in various strains of Salmonella enterica (abequose, tyvelose, paratose and colitose), while among serotypes of Yersinia pseudotuberculosis, all five including ascarylose are present (Lüderitz et al., 1971). Considering the evolutionary distance between Salmonella and Yersinia (Brenner, 1978), the simultaneous occurrence of this otherwise unknown polymorphism is somewhat surprising. The genetic principles underlying LPS formation have been most extensively studied in S. enterica LT2 (serovar typhimurium, group B) as a model system (Mäkelä \& Stocker, 1984).

In Salmonella, the $r f b$ cluster includes all the genes necessary for the synthesis of the $O$ unit sugar components and their subsequent assembly. The $r f b$ region of $S$. enterica LT2 has been cloned, sequenced and analysed (Brahmbatt et al., 1988; Jiang et al., 1991; Verma et al., 1988; Wyk \& Reeves, 1989; Liu et al., 1991): most of the genes necessary for formation of the $\mathrm{O}$ unit backbone including three genes from the abequose biosynthetic pathway $(r f b F$ and $r f b G$ coding for the two enzymes initiating abequose formation, and $r f b J$ coding for abequose synthase) have been allocated to specific open reading frames, while other genes such as $r f b H$ and $r f b I$ of the abequose pathway have only been located approximately (Fig. 1). Sequence analysis has revealed an unusually low $\mathrm{G}+\mathrm{C}$ content for the entire LT2 rfb region, suggesting a relatively recent transfer of the gene cluster to $S$. enterica from a non-enterobacterial donor with low $\mathrm{G}+\mathrm{C}$ content; the data indicate that the $r f b$ 


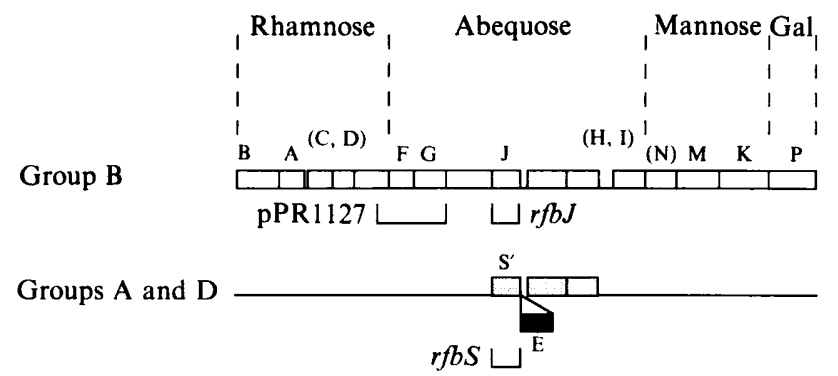

Fig. 1. Polymorphism of the $r f b$ gene cluster in $S$. enterica serovar typhimurium, typhi and paratyphi A (serogroups B, D, and A, respectively). Above: The $r f b$ gene cluster of $S$. enterica SL1654 (serogroup B). Open reading frames which have been identified are given their $r f b$ designation (A, B, etc.). The approximate positions of $r f b C, r f b D, r f b H$ and $r f b I$ are also given (Jiang et al., 1991). The boundary between the groups of genes involved in the four sugar pathways is indicated above, and the location of the DNA fragments used for hybridization (pPR 1127 and $r f b J$ ) experiments are indicated by brackets below. Below : the $r f b$ gene cluster of strain Ty2 (group D). Regions of near identity are shown as a simple line. Stippled areas indicate low homology (Verma et al., 1988, 1989). The $r f b E$ gene is not present in group B (dark area = no homology). The strain IMVS1316 (group A) $r f b$ region (allowing synthesis of the dideoxyhexose paratose) differs from the group $\mathrm{D} r f b$ region (determining tyvelose synthesis) essentially by a single point mutation in the $r f b E$ gene, resulting in the loss of the CDP-tyvelose-2-epimerase function (Verma et al., 1989). The position of the DNA region used for hybridization experiments $(r f b S)$ is indicated by the bracket below.

gene cluster itself may have been formed by combination of DNA segments derived from various sources, before being transferred to $S$. enterica (Jiang et al., 1991). Other $S$. enterica serovars such as typhi (group D) and paratyphi A (group A) possess an $\mathrm{O}$ antigen backbone structure similar to that of strain LT2 (containing mannose, rhamnose and galactose), but feature different immunodominant 3,6-dideoxyhexose side chains, such as tyvelose and paratose, respectively (Lüderitz et al., 1971). DNA segments responsible for the synthesis of the common $\mathrm{O}$ antigen backbone are in general highly conserved in all three strains, while the abequose region present in $S$. enterica LT 2 is replaced by a tyvelose region in strain Ty2 (serovar typhi), or a paratose region in strain IMVS1316 (serovar paratyphi A) (Fig. 1; Verma \& Reeves, 1989; Verma et al., 1988, Liu et al., 1991).

Tentative models for the LPS structures formed by the various $Y$. pseudotuberculosis serotypes have been proposed (Samuelsson et al., 1974); in the case of serotype IIA, D-galactose, 6-deoxyheptose and abequose appear to be the major $\mathrm{O}$ antigen constituents (Fig. 2). Serotype IA and IVB $O$ antigens seem to share the same structure and sugar composition, only differing in the replacement of abequose by paratose or tyvelose, respectively. LPS structures of other serotypes (IB, IIB, III, IVA, VA, VB) consist of a D-mannose-L-fucose sugar backbone, with a 3,6-dideoxyhexose derivative linked to either the man-

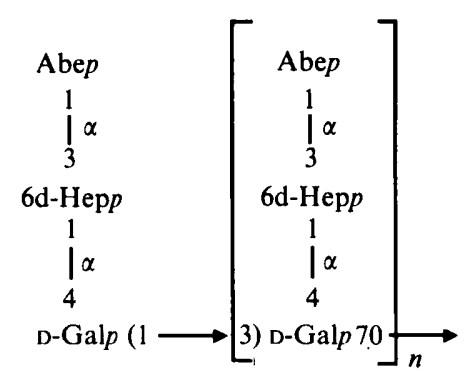

Fig. 2. Structure of the O-specific side chains of $Y$. pseudotuberculosis serogroup IIA (Samuelsson et al., 1974).

nose or the fucose residue. The genetic principles underlying a 3,6-dideoxyhexose polymorphism in $Y$. pseudotuberculosis have not been studied as yet. Extension of our studies on $r f b$ genes to $Y$. pseudotuberculosis should provide interesting information on the evolution of the 3,6-dideoxyhexose polymorphism in particular, and $O$ antigen variation in general.

Here we report the cloning in one functional piece of the entire $r f b$ region of $Y$. pseudotuberculosis serogroup IIA, which features abequose as an immunodominant LPS sugar. The minimal region required for expression of the $O$ antigen was identified, and subsequently subcloned.

\section{Methods}

Bacterial strains, cloning vectors and transposons. E. coli $\mathrm{K} 12, S$. enterica and $Y$.pseudotuberculosis strains used are listed in Table 1; all strains were cultivated in LB broth as described by Maniatis et al. (1982). The low copy number cosmid pPR69l (Jiang et al., 1987) was used as a cloning vector for the construction of the $Y$.pseudotuberculosis M85 gene bank, to avoid possible lethal effects of a high copy number of the $r f b$ gene cluster; kanamycin $\left(50 \mu \mathrm{g} \mathrm{ml}^{-1}\right)$ was used in this case for plasmid selection. The plasmid pUC18 (Yanisch-Perron et al., 1985) was used as a cloning vector for the construction of all subclones except pPR 1197. All plasmids based on pUC18 (including pPR1127) were selected for with ampicillin $\left(50 \mu \mathrm{g} \mathrm{ml}^{-1}\right)$. E. coli strain $\mathrm{S} 17-1$ served as a donor for the transposon Tn5-B50 (Samuelsson et al., 1974).

Enzymes, chemicals and antisera. Restriction enzymes, DNA polymerase I, RNAase A, proteinase $K$, pronase, bacterial alkaline phosphatase and T4 DNA ligase were purchased from Boehringer; Taq polymerase was purchased from Pharmacia; DNAase I and chemicals were obtained from Sigma and Ajax Chemicals. S. enterica O4-specific antiserum was purchased from Wellcome Diagnostics. The 'Packagene' kit from Promega was used for in vitro packaging of recombinant DNA. Nitrocellulose for colony blotting was obtained from Schleicher and Schuell.

DNA techniques. DNA extraction, general DNA manipulation methods and transformation were carried out as described by Maniatis et al. (1982). Southern hybridization was carried out overnight at $37^{\circ} \mathrm{C}$. For low stringency conditions, the hybridization solution contained $30 \%(\mathrm{v} / \mathrm{v})$ formamide, and washing was carried out at room temperature in $2 \times \mathrm{SSC}, 0.1 \% \mathrm{SDS}$; for high stringency conditions, $50 \%$ 
Table 1. Bacterial strains

\begin{tabular}{|c|c|c|c|}
\hline Strain & $\begin{array}{l}\text { Our stock no. } \\
\text { (if different) }\end{array}$ & Characteristics & $\begin{array}{l}\text { Source or } \\
\text { reference }\end{array}$ \\
\hline \multicolumn{4}{|c|}{ Escherichia coli $\mathrm{K} 12$} \\
\hline$\chi 2819$ & P3851 & $\begin{array}{l}\text { lacY1 glnV44 galK2 galT22 metB1 } \triangle \text { thy } A 57 \\
\text { gsdR2 recA56 }\end{array}$ & Jacobs et al. (1986) \\
\hline $\mathrm{S} \phi 874$ & P4052 & $\begin{array}{l}\text { lacZ4503 trp-355 upp-12 relA rpsL150 } \Delta(s b c- \\
\text { rfb } 86\end{array}$ & $\begin{array}{l}\text { Neuhard \& Thomassen } \\
\text { (1976) }\end{array}$ \\
\hline JM109 & P3584 & $\begin{array}{l}\text { supE44 gyrA96 recAl relAl endA thi hsdR17 } \\
\Delta(\text { pro-lac })\end{array}$ & $\begin{array}{l}\text { Yanisch-Perron et al. } \\
\text { (1985) }\end{array}$ \\
\hline $\begin{array}{l}\text { S17-1 } \\
\text { P4309 } \\
\text { P4554 }\end{array}$ & P4498 & $\begin{array}{l}\text { recA end } A \text { thi pro hsdR pSUP ::Tn5-B50 } \\
\chi 2819 \text { carrying pPR981 } \\
\text { JM109 carrying pPR } 1197\end{array}$ & $\begin{array}{l}\text { Simon et al. (1989) } \\
\text { This study } \\
\text { This study }\end{array}$ \\
\hline \multicolumn{4}{|c|}{ Yersinia pseudotuberculosis } \\
\hline M85 & & Wild-type, serogroup IIA & $\begin{array}{l}\text { Denise Hughes, NSW } \\
\text { Dairy Corp. Laboratories }\end{array}$ \\
\hline \multicolumn{4}{|c|}{ Salmonella enterica } \\
\hline SL1654 & P9003 & $\begin{array}{l}\text { Strain LT2, metE551 metA22 hsdL trpB2 flaA66 } \\
n m l \text { rpsL xylT404 ilv-452 hsdA }\end{array}$ & Ornellas \& Stocker (1974) \\
\hline P9029 & & Strain LT2, $\Delta($ his D-rfb)-388 & Nikaido et al. (1967) \\
\hline Ty2la & M18 & Serovar typhi, galE mutant of Ty2 & Germanier \& Furer (1975) \\
\hline
\end{tabular}

(v/v) formamide was used, and a further wash of $1 \mathrm{~h}$ at $56^{\circ} \mathrm{C}$ in $1 \times$ SSC, $0.1 \%$ SDS was added (Howley et al., 1979). A genomic DNA library from strain M85 was constructed as described by Bates \& Swift (1983), using the low copy number vector pPR691 (Jiang et al., 1987). The recombinant DNA was packaged in vitro, and E. coli $\chi 2819$ was transfected with the lysate.

The $S$. enterica LT2 gene $r f b J$ and the $S$. enterica Ty2 gene $r f b S$ were amplified in vitro using PCR as described by Saiki et al. (1988). Transposon mutagenesis was carried out using a modification of the protocol outlined by Simon et al. (1989): overnight cultures of the donor strain S17-1 (carrying the transposon Tn5-B50 on a mobilizable plasmid) and recipient strain P4309 (carrying the M85 rfb region on pPR981) were mixed and incubated for $3 \mathrm{~h}$ at $30^{\circ} \mathrm{C}$ to allow conjugation. Cells were spread onto plates containing kanamycin and tetracycline, thereby selecting for the presence of both the cosmid and the transposon. Isolated colonies were grown to an $\mathrm{OD}_{530}$ of $0 \cdot 3$, and in vivo packaging of the cosmid DNA was induced by heat shock (Jacobs et al., 1986). Bacterial cells were then lysed by treatment with chloroform, and cellular debris was removed by centrifugation. After filter sterilization, the phage lysate obtained was used to reinfect $E$. coli $\chi 2819$, which was then plated onto media containing kanamycin and tetracycline. Only in cases where the transposon had inserted into the cosmid was a simultaneous transfer of both resistance markers to the host strain possible, thereby allowing specific selection for the desired recombinant clones.

Immunochemical procedures. Slide agglutination tests were carried out as outlined by Leinonen (1985). For screening of large numbers of colonies, a modification of the protocol described by Hawkes et al. (1982) was used. Agar plates with colonies to be screened were overlaid with nitrocellulose discs, and incubated at $37^{\circ} \mathrm{C}$ for $1 \mathrm{~h}$. The cells bound to the filter were then lysed in situ by placing the discs for $30 \mathrm{~min}$ onto Whatman $3 \mathrm{MM}$ paper wetted with $0.5 \mathrm{M}-\mathrm{HCl}$. Cell debris was removed by washing with saline, and non-specific protein binding sites were blocked by incubation with $5 \%(\mathrm{w} / \mathrm{v})$ skimmed milk powder in TTBS (TBS $+0.05 \%$ Tween 20 ; TBS $=20 \mathrm{~mm}$-Tris $/ \mathrm{HCl}, 200 \mathrm{~mm}-$ $\mathrm{NaCl}, \mathrm{pH} 7.4)$. Incubation of the filters with O4-specific antibody (diluted $1: 1000$ in TTBS) for $1 \mathrm{~h}$ was followed by three washes with TTBS to remove unbound antibodies. Goat anti-rabbit IgG-horse- radish peroxidase conjugate was diluted 1:5000 in TTBS, added to the filters, and left to incubate for $1 \mathrm{~h}$. Subsequent extensive washing (four times with TTBS, twice with TBS) was followed by addition of staining substrate (4-chloro-1-naphthol and hydrogen peroxide) in TBS.

Extraction of LPS, SDS-PAGE and silver staining. Cells from a $10 \mathrm{ml}$ overnight culture were washed with saline, then resuspended in $2 \mathrm{ml}$ acetone before drying in a vacuum oven at $50^{\circ} \mathrm{C}$. Crude LPS was extracted with $90 \%(\mathrm{v} / \mathrm{v})$ phenol as outlined by Johnson \& Perry (1975), then further purified by treatment with DNAase I and RNAase A $\left(0.1 \mathrm{mg} \mathrm{ml}{ }^{-1}\right.$ final concentration of each) for $4 \mathrm{~h}$ at $37^{\circ} \mathrm{C}$, followed by an overnight incubation with pronase $\left(0 \cdot 1 \mathrm{mg} \mathrm{m}^{-1}\right)$. After overnight dialysis of the sample against water, its volume was reduced to about $50 \mu \mathrm{l}$ in a vacuum oven at $50^{\circ} \mathrm{C}$. To this $50 \mu \mathrm{l} 2 \times$ loading buffer (Lugtenberg et al., 1975) was added; 1-5 $\mu$ l of the sample was boiled for $5 \mathrm{~min}$ in a total volume of $20 \mu \mathrm{l} 1 \times$ loading buffer, then $1 \mu \mathrm{l}$ proteinase $\mathrm{K}\left(25 \mu \mathrm{g} \mathrm{mol}^{-1}\right)$ was added. SDS-PAGE was carried out as described by Lugtenberg et al. (1975), using an $8 \%$ stacking gel and an $18 \%$ running gel containing $0.2 \%$ SDS. For silver staining of LPS, the protocol developed by Hitchcock \& Brown (1983) was used.

\section{Results}

\section{Cloning of the M85 $r f b$ region}

A gene library of 800 colonies containing chromosomal DNA of $Y$. pseudotuberculosis M85 (serogroup IIA) was established by transfection of E. coli $\chi 2819$. As abequose is the common immunodominant $\mathrm{O}$ antigen sugar in $S$. enterica LT2 and $Y$. pseudotuberculosis M85, abequosespecific $\mathrm{O} 4$ antiserum raised against strain LT2 was a suitable agent to screen the gene library obtained. One clone, P4309, containing the recombinant cosmid pPR981, was detected by colony blotting and used for further analysis. The cosmid pPR981 was transferred 
(a)

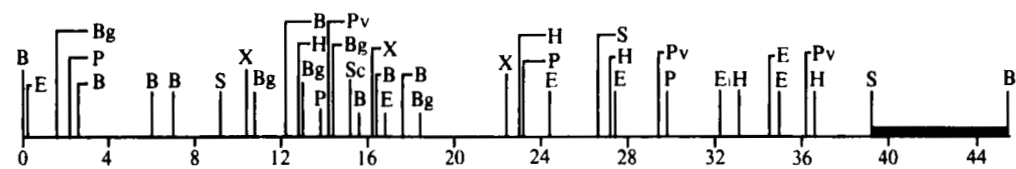

pPR981

\begin{tabular}{llll} 
& \multicolumn{1}{l}{} & & 1 \\
\hline $\mathrm{pPR} 1212$ & $\mathrm{pPR} 1213$ & $\mathrm{pPR} 1214$
\end{tabular}

(b)

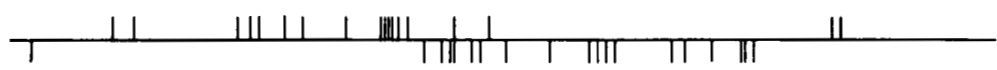

$(c)$

$$
\text { pPR } 1197
$$

(d)
Fig. 3. (a). Detailed restriction map of the cosmid pPR981, derived by combining the maps of the plasmids pPR1212, pPR1213, and pPR 1214 (map positions in kb). B, BamHI; Bg, BglII; E, EcoRI; H, HindIII ; P, PstI, Pv, PvuII ; S, SalI ; Sc, SacI; X, XhoI. The dark area indicates the position of the vector pPR691. (b). Distribution of Tn5-B50 insertion sites in pPR981. The vertical lines below the horizontal bar $(T)$ indicate insertions which inhibited $O$ antigen formation; vertical lines above the horizontal bar $(\perp)$ indicate insertions which did not inhibit $O$ antigen formation. (c) The cut-down plasmid pPR1197, which confers 04 cross-reacting antigen upon $E$. coli $\mathrm{K} 12$. (d) DNA fragments hybridizing to $S$. enterica LT2 3,6- dideoxyhexose biosynthesis pathway genes $r f b F$ or $r f b G$. into $E$. coli $\mathrm{S} \phi 874$, which carries a chromosomal deletion covering the whole $r f b$ region. Agglutination of the transformants with $\mathrm{O} 4$ antiserum suggested the presence of the complete M85 rfb region on the clone, as no complementation by the host $r f b$ functions was needed for $\mathrm{O}$ antigen expression.

\section{Restriction enzyme mapping}

After making a preliminary restriction map, three plasmids, pPR1212, pPR1213 and pPR1214, together covering the full length of the cosmid pPR981, were isolated by digestion of pPR981 with SalI, ligation into pUC18 and transformation into E. coli JM109. The clones were subsequently analysed in detail using suitable restriction enzymes to give the complete map presented in Fig.3.

\section{Localization of the rfb region by transposon mutagenesis}

Tn5-B50, a derivative of the transposon $\operatorname{Tn} 5$, was used for insertion mutagenesis of the cosmid clone pPR981, as described in Methods. All colonies showing both transposon-borne tetracycline resistance and cosmidborne kanamycin resistance were isolated. The isolates were tested for production of $\mathrm{O}$ antigen by colony blotting and slide agglutination, and the location of each transposon insertion was mapped using HindIII and XhoI. Most insertions located between map positions 18.1 and 37.4 inhibited expression of the $O$ antigen, while insertions outside this area generally had no effect on $\mathrm{O}$ antigen production (Fig. 3). Thus, the position of the M85 $r f b$ gene cluster could be narrowed down to a DNA region $19.3 \mathrm{~kb}$ in length, from map position 18.1 to 37.4 in pPR981. Expression of $O$ antigen in occasional clones carrying transposons within this $19.3 \mathrm{~kb}$ region is thought to be due to its insertion into a non-essential region or perhaps initiation of transcription by the $n p t$ promoter present on the transposon Tn5-B50.

One clone carrying a transposon insertion well outside the region for $O$ antigen expression, but nevertheless inhibiting $O$ antigen production, was isolated. The question whether the actual transposon insertion or a second, as yet unidentified mutational event within the $r f b$ region caused this effect, was not investigated.

\section{Construction of a functional subclone}

Results from the transposon mutagenesis experiment indicated that the location of the $r f b$ region was within the terminal half of the cosmid, between map positions 18.1 and 37.4 (Fig. 3). A plasmid, pPR1197, was constructed by digesting the original cosmid pPR981 with $B a m \mathrm{HI}$ and religating the fragment carrying the vector, thereby removing most of the areas outside of the region thought to contain the $r f b$ locus. This construct was shown to determine the formation of O4-crossreacting antigen in both the original cloning host $E$. coli strain, JM109, and the $r f b$-deleted strain, E. coli $\mathrm{S} \phi 874$.

\section{SDS-PAGE of $O$ antigen}

The $\mathrm{O}$ antigens produced by the E. coli strains $\mathrm{P} 4309$, P4494 and P4554 were visualized by silver staining of whole LPS phenol extracts after SDS-PAGE (Fig. 4). Both plasmids pPR981 and pPR1197 allowed formation of long chain LPS structures in E. coli K12 transformants with the $\mathrm{K} 12 r f b$ region present ( $\chi 2819$ or JM109). LPS chains determined by pPR1197 (lane 4) showed a 


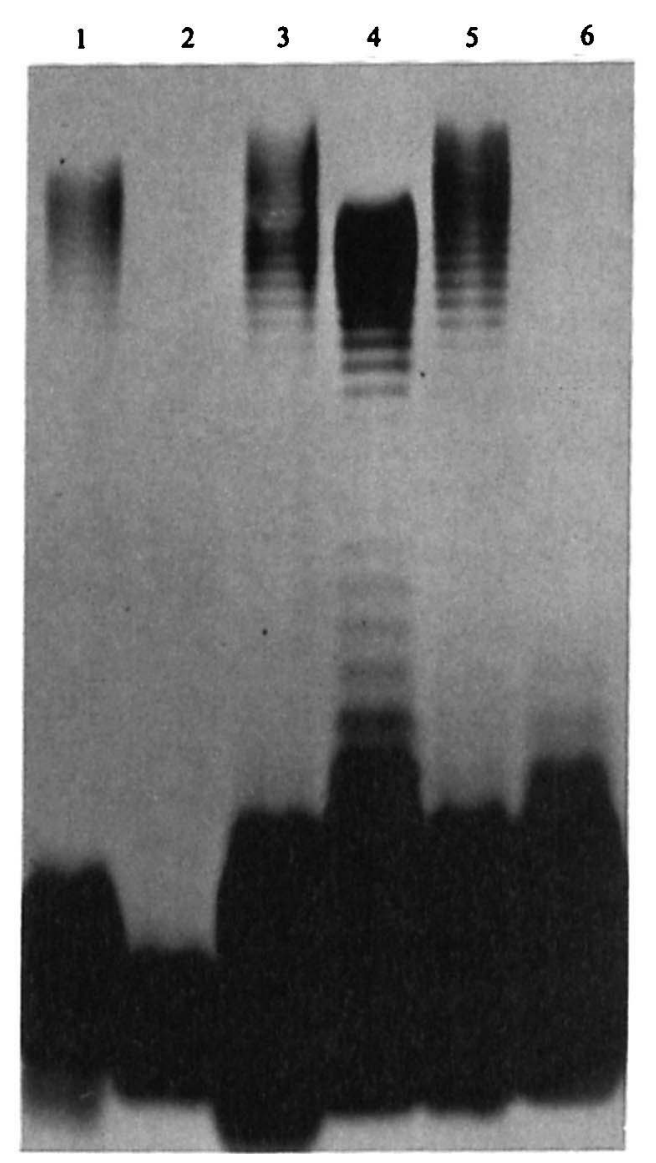

Fig. 4. SDS-PAGE of $O$ antigen produced by strains containing the $r f b$ region cloned from $Y$. pseudotuberculosis $\mathrm{M} 85$. Lanes: $1, \mathrm{M} 85 ; 2, \mathrm{~S} \phi 874$; 3, P4309 ( $\chi 2819$ containing pPR981); 4, P4554 (JM109 containing pPR1197); 5, S $\phi 874$ containing pPR981; 6, S $\phi 874$ containing pPR1197. $O$ antigen was visualized by silver staining.

different length distribution to chains determined by pPR981 (lane 3).

In the $r f b$-deleted strain S $\phi 874$, only pPR981 determined long chain LPS similar in appearance to the structures formed in other E. coli host strains (lane 5). The subclone pPR1197 in this strain only allowed the formation of short LPS chains with up to about five $O$ antigen units, slightly larger in size than the LPS core (lane 6).

\section{Southern hybridization}

Southern hybridization experiments were carried out using several 3,6-dideoxyhexose pathway genes from $S$. enterica to probe $Y$. pseudotuberculosis $\mathrm{M} 85$ chromosomal DNA and the cosmid pPR981 (positions of the probes within the respective $S$. enterica $r f b$ clusters are indicated in Fig. 1). The plasmid probe pPR 1127 (containing the $S$. enterica LT2 genes $r f b F$ and $r f b G$ ) hybridized to

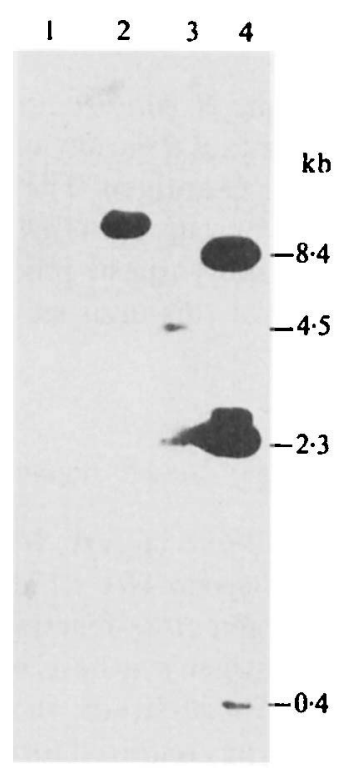

Fig. 5. Homology between $r f b$ regions of Salmonella and Yersinia. Probing of $Y$. pseudotuberculosis M85 chromosomal DNA with pPR1127, which contains the 3,6-dideoxyhexose biosynthesis pathway genes $r f b F$ and $r f b G$ of $S$. enterica SL1654 (group B). All DNAs were digested with $E c o R I$; probing was carried out under high stringency conditions. Lanes: $1-3$ chromosomal DNA: $1, S$. enterica P9029; $2, S$. enterica SL1654; 3, Y. pseudotuberculosis M85. Lane 4, pPR981 cosmid DNA cloned from Y. pseudotuberculosis M85. Sizes (in kb) of the fragments hybridizing are indicated; the hybridizing fragment slightly larger than $2.3 \mathrm{~kb}$ in the lane containing pPR981 is due to incomplete digestion of the cosmid DNA.

pPR981 under both low and high stringency conditions. The hybridizing fragments of M85 chromosomal DNA corresponded in size to those obtained with pPR981, confirming that no rearrangements had occurred during cloning (Fig. 5). However, the $8.4 \mathrm{~kb}$ cosmid DNA fragment hybridizing to PPR 1127 also contained a large segment of the cloning vector, and was therefore represented by a fragment of different size $(4.5 \mathrm{~kb})$ in the M85 chromosomal DNA. Stronger signals obtained with pPR981 cosmid DNA as compared to M85 chromosomal DNA are the consequence of a much higher copy number of the probed DNA fragment in the former case. The signals obtained with M85 chromosomal DNA were much weaker in comparison to those obtained with $S$. enterica chromosomal DNA controls, which indicates significant DNA sequence dissimilarities between the radioactive probes and the hybridizing M85 chromosomal fragments.

PCR-amplified DNA fragments containing the abequose synthase gene $r f b J$ from $S$. enterica LT2 or the paratose synthase gene $r f b S$ from $S$. enterica $T y 2$ failed to hybridize to either pPR 981 , or M85 chromosomal DNA, even under low stringency conditions (data not shown). 


\section{Discussion}

$Y$. pseudotuberculosis and S. enterica are the only species in nature known to contain a variety of 3,6-dideoxyhexose derivatives in their $O$ antigen. The cloning of the $Y$. pseudotuberculosis serogroup IIA $r f b$ region, which includes the abequose biosynthesis genes, is a first step in a closer investigation of this unusual polymorphism in Yersinia.

\section{Cloning and subcloning of the $r f b$ region}

We have cloned a $39 \mathrm{~kb}$ DNA fragment from $Y$. pseudotuberculosis serogroup IIA which determines the synthesis of an $\mathrm{O}$ antigen cross-reacting with $S$. enterica $\mathrm{O} 4$ antiserum. As $\mathrm{O}$ antigen synthesis was also conferred upon an $r f b$-deleted $E$. coli strain, the cosmid pPR981 must contain all the genes required for the synthesis and assembly of this structural component. The region responsible for $O$ antigen expression covered $19.3 \mathrm{~kb}$, as shown by transposon mutagenesis, and this region was subsequently subcloned to give the plasmid PPR 1197. This plasmid also conferred an O4-cross-reacting epitope upon the $r f b$-deleted $\dot{E}$. coli strain, showing that it still contained all the required genes.

\section{The $O$ antigen of original clone and subclone}

E. coli $\mathrm{K} 12$ transformants containing the original cosmid pPR981 or the subclone pPR1197 are believed to form a typical $Y$. pseudotuberculosis M85 $\mathrm{O}$ antigen unit: spacing of the $\mathrm{O}$ antigen ladder banding pattern after SDS-PAGE of membrane preparations was found to be similar to the wild-type pattern, suggesting structural identity of the $O$ units formed. The LPS patterns produced by strains containing plasmids pPR981 and PPR 1 197, however, differed significantly in the distribution of the $O$ antigen chain length: pPR981 allowed synthesis of long-chain $\mathrm{O}$ antigen in all E. coli hosts tested irrespective of their genotype, while in the case of pPR1197, the formation of long-chain O antigen was dependent on the presence of the host $r f b$ region. Recently, during the analysis of $r f b$ regions from $S$. enterica serogroup $\mathrm{C} 2$ and $E$. coli serogroup O111, similar observations led us to postulate an additional factor located within or near the $r f b$ region of $E$. coli $\mathrm{K} 12$, which is probably responsible for the determination of the chain length of a given LPS (Bastin et al., 1991; Brown et $a l ., 1991)$. DNA regions encoding such a factor were apparently present on pPR981, allowing the synthesis of $O$ antigen with a similar LPS chain length distribution in all $E$. coli host strains tested. Subcloning probably removed this region in PPR1197, with complementation of the missing determinant by the $E$. coli host factor giving the long-chain LPS phenotype in strain P4554. The predominance of shorter LPS chains in this strain may be a consequence of a different chain length specificity of the complementing host determinant. The $r f b$-deleted $E$. coli host strain $\mathbf{S} \phi 874$ on the other hand was unable to supply the missing chain length determinant, and therefore produced only short-chain $\mathrm{O}$ antigen when carrying pPR 1 197. The presence of polymerized O antigen in all K12 transformants carrying pPR981 or pPR1197 indicates the participation of an $\mathrm{O}$ antigen polymerase (coded for by $r f c$ ) in the LPS formation process (Mäkelä \& Stocker, 1984). This function may either be provided by a $Y$. pseudotuberculosis gene present on the recombinant plasmids, or be complemented by the $\mathrm{O}$ antigen polymerase of $E$. coli $\mathrm{K} 12$. The latter seems unlikely as $r f c$ function appears to be very specific (Mäkelä \& Stocker, 1984).

\section{Relationship of $S$. enterica abequose genes to the $Y$. pseudotuberculosis IIA rfb region}

In order to compare the genes responsible for the biosynthesis of 3,6-dideoxyhexoses in Salmonella and Yersinia, Southern hybridization experiments using $S$. enterica 3,6-dideoxyhexose genes to probe the cloned $Y$. pseudotuberculosis M85 rfb DNA region were carried out. The $S$. enterica LT2 genes $r f b F$ and $r f b G$ showed a significant level of similarity to the M85 $r f b$ region, whilst the abequose synthase gene $r f b J$ of the same Salmonella strain has no apparent homologous equivalent in Y. pseudotuberculosis M85. Similarly, the paratose synthase gene $r f b S$ from $S$. enterica Ty2 also failed to hybridize to the cloned DNA region. $R f b S$ has previously been shown to be distantly related to $r f b J$ with $46 \%$ sequence similarity (Verma \& Reeves, 1989). Thus it appears that different genes of the abequose biosynthetic pathway in $Y$. pseudotuberculosis M85 have different ancestral histories. Whilst $r f b F$ and $r f b G$ in Salmonella and Yersinia have been derived from a common source, the genes for abequose synthase $(r f b J)$ in both organisms seem to have originated from independent sources or alternatively, if they have derived from the same source, they have undergone significant sequence divergence since their separation, as detected by Southern hybridization.

Although a common origin for at least some of the 3,6dideoxyhexose biosynthetic genes of $Y$. pseudotuberculosis M85 and $S$. enterica seems likely, their common ancestor is unlikely to be the source of the $r f b$ genes: the Salmonella $r f b$ region is thought to have originated from an unrelated non-enterobacterial donor (Wyk \& Reeves, 1989). The $r f b$ gene transfer into $S$. enterica is believed to have taken place in a relatively recent event, after its 
divergence from E. coli (Jiang et al., 1991; Verma \& Reeves, 1989; Wyk \& Reeves, 1989). The separation of Yersinia and Salmonella is thought to be much more ancient than that of Salmonella and $E$. coli (Brenner, 1978), but the time of entry of the $r f b$ genes into Yersinia is unknown at present. The considerable differences in DNA sequence of Salmonella and Yersinia abequose genes, as shown by Southern hybridization experiments, suggest that the two gene sets have been separated for quite some time, which may indicate a much earlier time for the $r f b$ gene transfer into Yersinia than for Salmonella.

Sequence analysis of the cloned $r f b$ region will allow more precise statements about relationship, homology and history of the DNA regions determining 3,6dideoxyhexose synthesis in both Yersinia and Salmonella, and will lead to a better understanding of the evolution of $\mathrm{O}$ antigen variation.

This work was supported by a grant from the Australian Research Council.

\section{References}

Bastin, D. A., Romana, L. K. \& Reeves, P. R. (1991). Molecular cloning and expression in Escherichia coli $\mathrm{K}-12$ of the $r f b$ gene cluster determining the $\mathrm{O}$ antigen of an E. coli O111 strain. Molecular Microbiology 5 (in the Press).

Bates, P. F. \& SwIFT, R. A. (1983). Double cos site vectors: simplified cosmid cloning. Gene 26, 137-146.

Brahmbatt, H. N., WyK, P., Quigley, N. B. \& Reeves, P. R. (1988). Complete physical map of the $r f b$ gene cluster encoding biosynthetic enzymes for the $\mathrm{O}$ antigen of Salmonella typhimurium LT2. Journal of Bacteriology 170, 98-102.

BRENNER, D. J. (1978). Characterization and identification of Enterobacteriaceae by DNA hybridization. In Progress in Clinical Pathology, pp. 71-117. Edited by M. Stefanini. New York: Grune \& Stratton.

Brown, P. K., Romana, L. K. \& Reeves, P. R. (1991). Cloning of the $r f b$ gene cluster of a group C2 Salmonella: comparison with the $r f b$ regions of groups B and D. Molecular Microbiology 5, 1873-1881.

GERMANIER, G. \& FURER, R. (1975). Isolation and characterization of gal $E$ mutant Ty2la of Salmonella typhi: a candidate strain for a live, oral typhoid vaccine. Journal of Infectious Diseases 131, 553-558.

HaWkes, R., Niday, E. \& GoRdon, J. (1982). A dot-immunobinding assay for monoclonal and other antibodies. Analytical Biochemistry 119, $142-147$.

HitchCOCK, P. J. \& Brown, T. M. (1983). Morphological heterogeneity among Salmonella lipopolysaccharide chemotypes in silverstained polyacrylamide gels. Journal of Bacteriology 154, 269-277.

Howley, P. M., ISRael, M. A., LaW, M. F. \& Martin, M. A. (1979). A rapid method for detecting and mapping homology between heterologous DNAs. Journal of Biological Chemistry 254, 4876-4883.

Jacobs, W. R., Barrett, J. F., Clark-Curtiss, J. D. \& Curtiss, R. (1986). In vivo repackaging of recombinant cosmid molecules for analyses of Salmonella typhimurium, Streptococcus mutans, and mycobacterial genomic libraries. Infection and Immunity 52, 101-109.

Jiang, X. M., Brahmbatt, H. N., Quigley, N. B. \& Reeves, P. R. (1987). A low copy number cosmid. Plasmid 18, 170-172.
Jiang, X. M., Neal, B., Santiago, F., Lee, S. J., Romana, L. K. \& ReEves, P. R. (1991). Structure and sequence of the $r f b$ (O antigen) gene cluster of Salmonella serovar typhimurium (strain LT2). Molecular Microbiology 5, 695-713.

Johnson, K. G. \& PERRY, M. B. (1975). Improved techniques for the preparation of bacterial lipopolysaccharides. Canadian Journal of Microbiology 22, 29-34.

LEINONEN, M. (1985). Serological methods for the study of bacterial surface antigens. In Enterobacterial Surface Antigens: Methods for Molecular Characterisation, pp. 179-206. Edited by T. K. Korhonen, E. A. Dawes \& P. H. Mäkelä. Amsterdam: Elsevier Science Publishers.

LiU, D., Verma, N. K., Romana, L. K. \& Reeves, P. R. (1991). Completing the sequence of the $r f b$ region of Salmonella serovars typhi (group D) and paratyphi (group A): relationship with group B. Journal of Bacteriology 173, 4814-4819.

Lüderitz, O., Westphal, O., Staub, A. M. \& Nikaido, H. (1971). Isolation and chemical and immunological characterization of bacterial lipopolysaccharides. In Microbial Toxins, pp. 145-233. Edited by G. Weinbaum, S. Kadis \& S. J. Ajl. New York: Academic Press.

Lugtenberg, B., Meijers, J., Peters, R., van der Hoek, P. \& VanALPHEN, L. (1975). Electrophoretic resolution of the 'major outer membrane protein' of Escherichia coli K-12 into four bands. FEBS Letters 58, 254-258.

MÄKELÄ, P. H. \& STOCKER, B. A. D. (1984). Genetics of lipopolysaccharide. In Handbook of Endotoxin, pp. 59-137. Edited by E. T. Rietschel. Amsterdam: Elsevier Science Publishers.

Maniatis, T., Fritsch, E. F. \& Sambrook, J. (1982). Molecular Cloning: a Laboratory Manual. Cold Spring Harbor, NY: Cold Spring Harbor Laboratory.

NeUhaRD, J. \& ThOMASSEN, E. (1976). Altered deoxyribonucleotide pools in P2 eductants of Escherichia coli K-12 due to deletion of the dcd gene. Journal of Bacteriology 126, 999-1001.

Nikaido, H., Levinthal, M., Nikaido, K. \& Nakane, K. (1967). Extended deletions in the histidine-rough-B region of the Salmonella chromosome. Proceedings of the National Academy of Sciences of the United States of America 57, 1825-1832.

Ornellas, E. P. \& Stocker, B. A. D. (1974). Relation of lipopolysaccharide character to $\mathrm{Pl}$ sensitivity in Salmonella typhimurium. Virology 60, 491-502.

Saiki, R. K., Gelfand, D. H., Stofell, S., Scharf, S. J., Higuchi, R., HORN, G. T., Mullis, K. B. \& Ehrlich, H. A. (1988). Primer directed enzymatic amplification of DNA with a thermostable DNA polymerase. Science $239,487-491$.

SAMUELSSON, K., LINDBERG, B. \& BRUBAKER, R. R. (1974). Structure of $\mathrm{O}$-specific side chains of lipopolysaccharides from Yersinia pseudotuberculosis. Journal of Bacteriology 117, 1010-1016.

Simon, R., QuANDT, J. \& KLIPP, W. (1989). New derivatives of transposon $\operatorname{Tn} 5$ suitable for mobilization of replicons, generation of operon fusions and induction of genes in Gram-negative bacteria. Gene 80, 161-169.

VERMA, N. \& REEVES, P. R. (1989). Identification and sequence of $r f b S$ and $r f b E$, which determine antigenic specificity of group $A$ and group D salmonellae. Journal of Bacteriology 171, 5694-5701.

Verma, N. K., Quigley, N. B. \& Reeves, P. R. (1988). O-antigen variation in Salmonella spp. : $r f b$ gene clusters of three strains. Journal of Bacteriology 170, 103-107.

WYK, P. \& REEVES, P. R. (1989). Identification and sequence of the gene for abequose synthase which confers antigenic specificity on group B Salmonellae: homology with galactose epimerase. Journal of Bacteriology 171, 5687-5693.

Yanisch-Perron, C., Vieira, J. \& Messing, J. (1985). Improved M13 phage cloning vectors and host strains; nucleotide sequences of the M13mp18 and pUC19 vectors. Gene 33, 103-119. 